\title{
Vagrant Subantarctic fur seal in the Mayumba National Park, Gabon
}

\author{
R. Zanre' \& M.N. Bester ${ }^{2 *}$ \\ ${ }^{1}$ Mayumba Project Manager, Wildlife Conservation Society, BP7847, Libreville, Gabon \\ ${ }^{2}$ Mammal Research Institute, Department of Zoology and Entomology, University of Pretoria, Pretoria, 0002 South Africa
}

Received 15 October 2010. Accepted 19 December 2010

\begin{abstract}
A vagrant adult male Subantarctic fur seal Arctocephalus tropicalis was seen and photographed on the beach in Mayumba National Park in the Gabonese Republic. This is the northern most sighting on record for the species. The likely source of the vagrant is the population at Gough Island, South Atlantic.
\end{abstract}

Key words: Arctocephalus tropicalis, Gabon, vagrant, dispersion.

$\mathrm{O}$ ne sighting on the 10th of September 2010 of an adult male Subantarctic fur seal (Arctocephalus tropicalis) was recorded on the beach of the Mayumba National Park, Gabonese Republic (Fig. 1). The northern boundary of the National Park stretches inland perpendicular to the coast for $1 \mathrm{~km}$, and runs parallel to the coast, southeastwards for $60 \mathrm{~km}$ to the Republic of the Congo border, creating a terrestrial zone of $60 \mathrm{~km}^{2}$. The seal (Fig. 2) was located in the vegetation zone of the beach at $03^{\circ} 41^{\prime} \mathrm{S}, 10^{\circ} 56^{\prime} \mathrm{E}$ about $1 \mathrm{~km}$ south of the Koubula camp and about $45 \mathrm{~km}$ from the border with the Congo. It appeared exhausted but was able to raise itself and adopt a defensive attitude, including vocalizing when approached. It had an eye injury, the eye being closed and swollen (Fig. 2a), and an injury to the head (Fig. 2b). Subsequent inspection of photographs taken revealed that it did not appear to be overly emaciated (Fig. 2) and had an unidentified goose barnacle attached to the pelage of the dorsal neck area (Fig. 2b). The fur seal was carried back to the camp, wrapped in a bed sheet, with the intention of feeding it fish. The seal was startled by the noise of a quad bike approaching and it headed for the sea. It was allowed to escape and it swam off not to be seen again.

Subantarctic fur seals swim vast distances, e.g. lactating females sometimes make return feeding trips in excess of $600 \mathrm{~km}$ distant from their breeding site (de Bruyn et al. 2009) and a tagged subadult male from Amsterdam Island $\left(37^{\circ} 50^{\prime} \mathrm{S}, 7^{\circ} 32^{\prime} \mathrm{E}\right)$

*Author for correspondence. E-mail: mnbester@zoology.up.ac.za was seen $7000 \mathrm{~km}$ to the west at Gough Island $\left(40^{\circ} 20^{\prime} \mathrm{S}, 9^{\circ} 54^{\prime} \mathrm{W}\right.$ ) amongst conspecifics (Hänel et al. 2005). Vagrant Subantarctic fur seals had been found as far south as the coast of Antarctica (Shaughnessy \& Burton 1986), and amongst Antarctic fur seals on South Georgia (Payne 1979) and Bouvetøya (Hofmeyr et al. 2006a). In South Africa with an inhabited coastline and a number of marine facilities, 22 animals have been recorded between June 1966 and June 1979, 13 (59\%) of which were adult males, three (14\%) subadult and six $(27 \%)$ females (Shaughnessy \& Ross 1980). An unconfirmed number has been recorded since then (e.g. Bester 1989) by three separate regional authorities, which would render incomplete the inclusion of known sightings of the species in temperate South Africa in Fig. 1. In the tropics, however, extralimital records on the Atlantic seaboard include two adult males found on the coast of Angola at 9 $20^{\prime} \mathrm{S}$ (Carr et al. 1985) and an immature male and female on the coast of Brazil between $9^{\circ} 40^{\prime} \mathrm{S}$ and $12^{\circ} 54^{\prime} \mathrm{S}$ (Neves et al. 1990; Pinedo 1990). In the Indian Ocean, an immature was found at Unguja (or Zanzibar) Island, Tanzania at $05^{\circ} 52^{\prime} \mathrm{S}$ (Hofmeyr \& Amir 2010), a juvenile on the Comore Islands at 12³0'S (David et al. 1993), one on the east coast of Madagascar at $22^{\circ} 08^{\prime} \mathrm{S}$ (Garrigue \& Ross 1996) and one on the island of Rodrigues at $19^{\circ} 43^{\prime} \mathrm{S}$. A further two were recorded on Mauritius at $20^{\circ} 30^{\prime} \mathrm{S}$ (David \& Salmon 2003).

Vagrant Subantarctic fur seals have not previously been recorded on the coast of Gabon, and the current sighting is the most northerly of a confirmed Subantarctic fur seal, with two vagrants, also adult males, found much further south on the west coast of Angola (Carr et al. 1985). The goose barnacle attached to the fur seal confirms that it has spent a long time at sea after settlement of the barnacle. Similarly, goose barnacles (Lepas australis) had also been recorded from conspecific females at Gough Island (Setsaas \& Bester 2006), the closest population of Subantarctic fur seals to Gabon at 


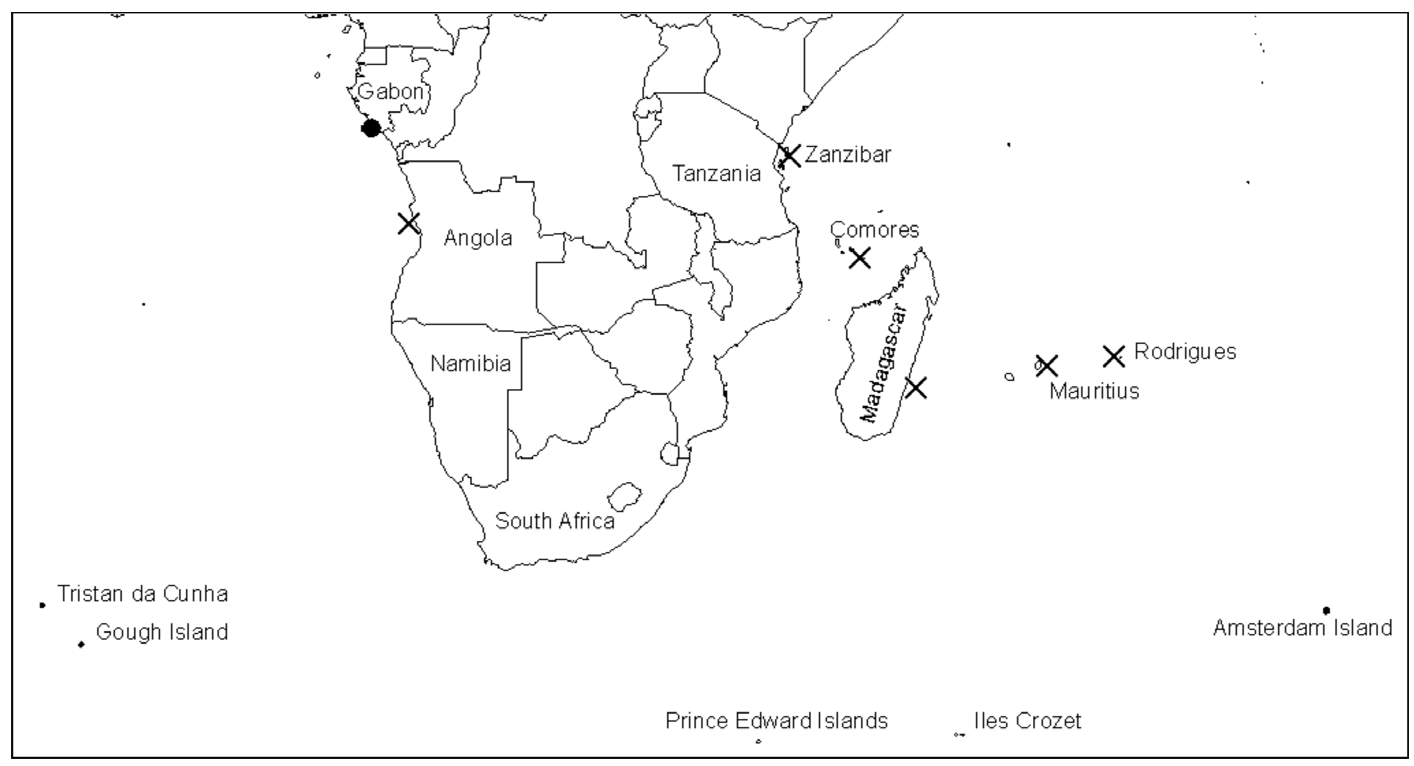

Fig. 1. Map showing location of most sites mentioned in the text. Crosses indicate the location of recorded vagrants of the Subantarctic fur seal (Arctocephalus tropicalis) in tropical Africa and nearby islands, and the filled circle shows the location of the sighting in Gabon.

$40^{\circ} 20^{\prime} \mathrm{S}, 9^{\circ} 54^{\prime} \mathrm{W}$, some $4500 \mathrm{~km}$ to the southsouthwest. This is the largest breeding population of the species and numbers well in excess of 200000 seals (Bester et al. 2006). The second largest breeding population numbering approximately 150000 fur seals (Hofmeyr et al. 2006b) is at the Prince Edward Islands (PEIs), approximately
$5600 \mathrm{~km}$ to the southeast of Mayumba National Park in Gabon, $1100 \mathrm{~km}$ further than Gough Island, at approximately $46^{\circ} \mathrm{S}, 38^{\circ} \mathrm{E}$. While either of these populations could be a source of the vagrant recorded in Gabon, fur seals from Gough Island would be assisted by the West Wind Drift to reach Africa, and then by the North Westerly Benguela

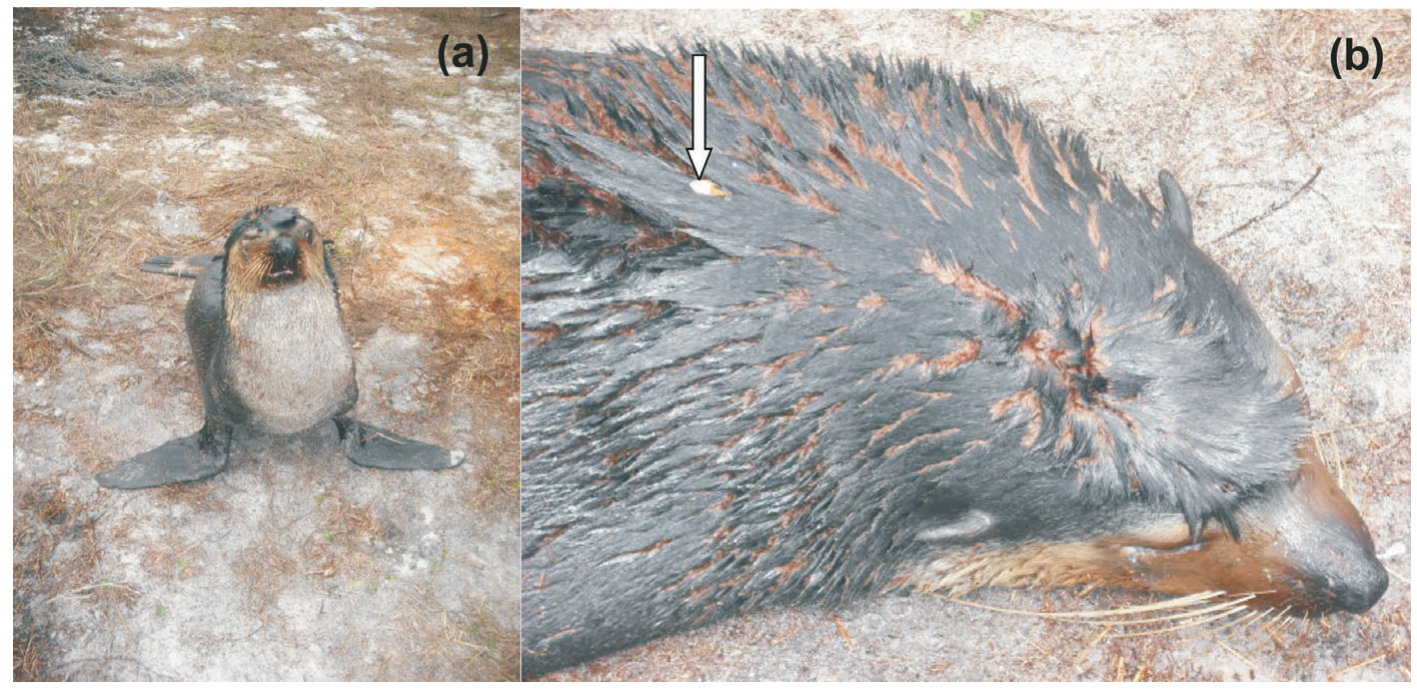

Fig. 2. The adult male Subantarctic fur seal seen on the coast of the Mayumba National Park, Gabonese Republic with (a) a closed, swollen right eye, and (b) a head wound and the goose barnacle (arrowed) attached to the pelage of the neck. 
Drift to migrate to the tropics and ultimately to reach Gabon, whereas seals from the PEIs would have had to swim against the Antarctic Circumpolar Current, across the Subtropical Convergence and then against the Agulhas Return Current. The second alternative is feasible, because a juvenile Subantarctic fur seal tagged at the PEIs had been sighted on the southwest coast of South Africa (Bester 1989). In addition, comparing the vagrant Subantarctic fur seals' mitochondrial DNA control sequences from Brazil to exclusive haplotypes from the main breeding colonies of the species, not all the vagrant individuals arrived from Gough Island (the closest breeding population site). Some also came from other breeding populations such as Iles Crozet (950 km east of the PEIs), approximately $16500 \mathrm{~km}$ from the Brazilian coast (Ferreira et al. 2007). Therefore, any of the major colonies of Subantarctic fur seals could have been the source for the vagrant in the present study. The continued reporting of extralimital vagrants improves our understanding of the species' dispersal and dispersion abilities and patterns.

Mayumba National Park is run by the Agence Nationale des Parcs Nationaux (ANPN), with WCS providing technical and logistical field support to park management. These observations were recorded during field patrols conducted by ANPN ecoguards and WCS staff. We are especially grateful to ANPN staff members Makoundi Pascal, Koumba Sene and Elie Ibouanga and WCS staff member Quevain Makaya for the locating and reporting of the vagrant; and to Quevain Makaya for the photographs. W.C.S. is grateful to donors USAID-Central African Regional Program for the Environment and EC-Central Africa World Heritage Finance Initiative for the financial support provided to field patrols. Mia Wege of the MRI produced the map.

\section{REFERENCES}

BESTER, M.N. 1989. Movements of southern elephant seals and Subantarctic fur seals in relation to Marion Island. Marine Mammal Science 5: 257-265.

BESTER, M.N., WILSON, J.W., BURLE, M-H. \& HOFMEYR, G.J.G. 2006. Population trend of Subantarctic fur seals at Gough Island. South African Journal of Wildlife Research 36: 191-194.

CARR, T., CARR, N. \& DAVID, J. H. M. 1985. A record of the sub-Antarctic fur seal Arctocephalus tropicalis in Angola. South African Journal of Zoology 20: 77.

DAVID, J.H.M., MERCER, J. \& HUNTER, K. 1993. A vagrant Subantarctic fur seal Arctocephalus tropicalis found in the Comores. South African Journal of Zoology 28: 61-62.

DAVID, J.H.M. \& SALMON, L. 2003. Records of the Subantarctic fur seal Arctocephalus tropicalis from Rodrigues and Mauritius, Indian Ocean. African Journal of Marine Science 25: 403-405.

DE BRUYN, P.J.N., TOSH, C.A., OOSTHUIZEN, W.C., BESTER, M.N. \& ARNOULD, J.P.Y. 2009. Bathymetry and frontal system interactions influence seasonal foraging movements of lactating subantarctic fur seals from Marion Island. Marine Ecology Progress Series 394: 263-276.

FERREIRA, J.M., DE OLIVEIRA, L.R., WYNEN, L., BESTER, M.N., GUINET, C., MORAES-BARROS, N., MARTINS, F.M., MUELBERT, M.M.C., MORENO, I.B., SICILIANO, S., OTT, P.H. \& MORGANTE, J.S. 2008. Multiple origins of vagrant Subantarctic fur seals: a long journey to the Brazilian coast detected by molecular markers. Polar Biology 31: 303-308.

GARRIGUE, C. \& ROSS, G.J.B. 1996. A record of the Subantarctic fur seal, Arctocephalus tropicalis, from Madagascar, Indian Ocean. Marine Mammal Science 12: 624-627.

HÄNEL, C., CHOWN, S., \& GASTON, K. 2005. Gough Island, A Natural History. SUN Publishers, Stellenbosch.

HOFMEYR, G.J.G., BESTER, M.N. \& KIRKMAN, S.P. 2006a. Vagrant Subantarctic fur seals at Bouvetøya. African Zoology 41: 145-146.

HOFMEYR, G.J.G., BESTER, M.N., MAKHADO, A.B. \& PISTORIUS, P.A. 2006b. Population changes in Subantarctic and Antarctic fur seals at Marion Island. South African Journal of Wildlife Research 36: 55-68.

HOFMEYR, G.J.G. \& AMIR, O.A. 2010. Vagrant Subantarctic fur seal on the coast of Tanzania. African Zoology 45: 144-146.

NEVES, M.L.C., REIS, M.S.S. \& BRASILEIRO, M.T.R. 1990. Sobre a ocorrência de Arctocephalus tropicalis (Gray, 1872) na Baia de Todos os Santos, Bahia, Brasil (Mammalia, Arctocephalinae). 4a Reunión de Trabajo de Especialistas en Mamíferos Acuáticos de América del Sur, November 1990, Valdivia, Chile: p. 47.

PAYNE, M.R. 1979. Fur seals Arctocephalus tropicalis and A. gazella crossing the Antarctic Convergence at South Georgia. Mammalia 43: 93-98.

PINEDO, M.C. 1990. Ocorrência de pinípedes na costa brasileira. Garcia de Orta, Séria Zoologia, Lisboa 15: 37-48.

SETSAAS, T.H. \& BESTER, M.N. 2006. Goose barnacle (Lepas australis) infestation of the Subantarctic fur seal (Arctocephalus tropicalis). African Zoology 41: 305-307.

SHAUGHNESSY, P.D. \& ROSS, G.J.B. 1980. Records of subantarctic fur seal (Arctocephalus tropicalis) from South Africa with notes on its biology and some observations of captive animals. Annals of the South African Museum 82 (2): 71-89.

SHAUGHNESSY, P.D. \& BURTON, H.R. 1986 Fur seals Arctocephalus spp. at Mawson Station, Antarctica, and in the Southern Ocean. Polar Record 23: 79-81.

Responsible Editor: J.H. van Wyk 